\title{
Differential Fatiguability of Human Skeletal Muscles
}

\author{
Haruhiko $\mathrm{SATO}^{1)}$ and Atsushi $\mathrm{HAYAMI}^{2)}$ \\ 1) Department of Ergonomics, Kyushu Institute for Design Research \\ 2) Division of Anthropology and Kinesiology, \\ Japan Women's College of Physical Education
}

\begin{abstract}
Fatiguability for sustained isometric contraction was investigated for human limb muscles by means of frequency analysis of the bipolar surface electromyogram. The contraction strength was two-thirds or a half of the maximum strength. The increase of slow wave ratio (the proportion of the integrated amplitude in the frequency component below $60 \mathrm{~Hz}$ to the total activity) in the electromyogram from initial slow wave ratio was calculated to evaluate muscle fatigue. The triceps brachii was more fatiguable than biceps brachii and brachioradialis, the extensor carpi ulnaris more than flexor carpi ulnaris, the semitendinosus more than rectus femoris, vastus medialis and vastus lateralis, and the tibialis anterior more than gastrocnemius and soleus. The muscles of lower limb, especially the knee extensors and the calf muscles, were less fatiguable than the muscles of upper limb. In the upper limb, the extensors were more fatiguable than the flexors. No consistent difference in fatiguability was observed between the one-joint and two-joint muscles. Differential fatiguability could be due to the differences in muscle fiber composition.
\end{abstract}

\section{INTRODUCTION}

Habitual bipedalism is the most significant of many characteristics that distinguish man from all other mammals. In the course of human evolution, the lower extremities became specialized for bipedalism, the foot losing most of its grasping ability. The freeing of the hands from locomotion duty made possible their use for delicate manual operations. These postural transformations of the body have been associated with a number of structual and functional changes (NAPIER, 1962, 1967). Functional differentiation of human skeletal muscles would reflect physical characteristics of man. Physio- logical differences have been found among several human muscles (Buchthal \& ScHMALBRUCH, 1970; KADEFORS et al., 1968; Kogi \& Hakamada, 1962a; Molbech \& Johansen, 1973; SAto, 1976; SAto et al., 1965; Tokizane \& Shimazu, 1964).

It is a well-established fact that local muscle fatigue causes a shift in the frequency spectrum of the surface electromyogram(EMG) towards lower frequencies (ChAFFin, 1973; KADEFors et al., 1968; Kogi \& HaKamada, 1962a; Sato, 1977). KogI \& HaKamada(1962b) found that the variation in the quotient of the electrically integrated amplitude of slower components of the surface EMG divided by that of the faster components was in 
good correspondence with the subjective grading of muscle fatigue. The surface EMG frequency shifts have been used to evaluate local muscle fatigue in relation to real work situations (KADEFORS et al., 1976; SAto \& IshiI, 1977; TANII et al., 1972) or posture (OKADA et al., 1970; SATo, 1966). Chaffin(1973) has used the EMG frequency shift for evaluating the specific levels of fatigue due to various sedentary work postures and arm loads. KADEFORS et al. (1968) and SATo et al. (1965) have revealed differential fatiguability of human skeletal muscles by the amount of spectral change of the surface EMG in fatiguing contractions.

It would be possible to compare the fatiguability of various muscles by applying the degree of frequency lowering of the surface EMG as an objective index of local muscle fatigue. It might be assumed that the greater the frequency lowering of the surface EMG the more fatiguable the muscle. The purpose of the present study is to investigate the functional differentiation of main human limb muscles from the viewpoint of fatiguability for sustained isometric contraction by means of frequency analysis of the surface EMG.

\section{METHODS}

The bipolar surface EMG was obtained by a pair of silver disc electrodes (10 mm in diameter) attached to the skin over the belly of the examined muscle, parallel to muscle fibers and spaced about $30 \mathrm{~mm}$ between centers. This EMG signal was amplified with a time constant of $0.1 \mathrm{sec}$ by a differential amplifier (frequency response: down $3 \mathrm{db}$ at $3.5 \mathrm{kHz}$ ) and recorded by a electroencephalograph (Nihon Kohden Kogyo Co., ME-92). The frequency spectra of the amplified EMG were obtained by an automatic frequency analyzing integrator(Nihon Kohden Kogyo Co., MAF-3) for each 5-sec period. Frequency ranges of its seven frequency band pass filters were 0-20, 20-40,40-60, $60-100,100-150,150-300 \mathrm{~Hz}$ and above 300 $\mathrm{Hz}$. Their frequency characteristics were shown previously (SATo, 1964).

A total of fifty-eight fatigue experiments were done for twelve muscles in seven normal subjects (four females and three males) ranging from 18 to 33 years of age. The examined muscles were the triceps brachii, biceps brachii, brachioradialis, extensor carpi ulnaris, flexor carpi ulnaris, semitendinosus, rectus femoris, vastus medialis, vastus lateralis, tibialis anterior, gastrocnemius and soleus. The contraction of the elbow extensor or flexors was performed using a special electrical tension-meter described by SATO \& SAKAI (1968) or by supporting a load at the wrist. In both cases the angle of the elbow was $90^{\circ}$, the forearm horizontally in supination and the wrist in the neutral position. As to the extensor and flexor carpi ulnaris, the contraction was performed by supporting a load at the metacarpal region of the hand with the same posture as the contractions of the elbow extensor and flexors. The subject contracted the thigh muscles against a load applied to the ankle with the knee extended in the contraction of the knee 
extensors and with the knee flexed to $90^{\circ}$ in the contraction of the knee flexor. The subject was seated and contracted the plantar flexors with the ankle at $90^{\circ}$ angle and the dorsiflexor with the ankle at $120^{\circ}$ angle, using an apparatus for fixing the ankle with strain-gauge described by SATo(1964).

In order to investigate the fatiguability for sustained isometric contraction of various muscles, uniform contraction strength of two-thirds (in most experiments) or of a half (in eight experiments) of the maximum voluntary contraction strength (MVC) was used. The contraction level was decided according to a linear relationship between the isometric tension and the integrated surface EMG (EDWARDS \& LiPPOLD, 1956 ; Kogi \& HAKAMADA, 1962b ; LipPold, 1952 ; SAdoyama \& Kogi, 1970 ; STEPHENS \& TAYLOR, 1972). In each experiment the muscle strength at which the integrated EMG for $2.5 \mathrm{sec}$ was twothirds or a half of that in the MVC was determined in the above-mentioned contraction conditions. This way might be suitable to provide the strength of individual muscle.

In the experiment, the subject contracted the examined muscle at a given tension isometrically until 'exhaustion' in a shielded room. The data analysis was started at the time when the contraction became stable.

\section{RESULTS}

The lowering in frequency spectrum of the surface EMG was observed during sustained isometric contraction. Fig. 1

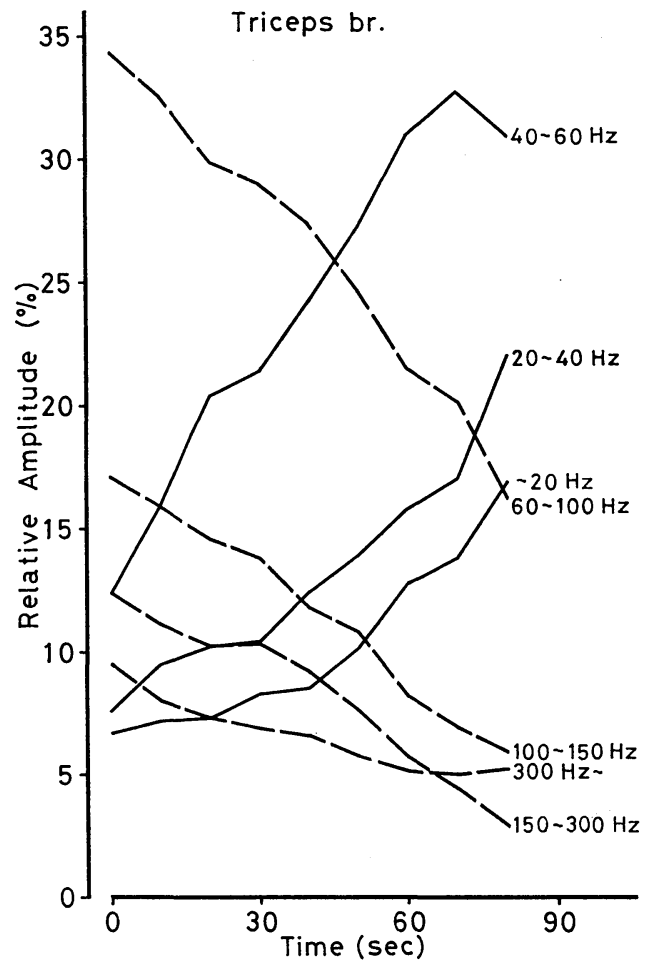

Fig. 1. Changes in the ratio of the integrated amplitude of each frequency band to the total activity in the EMG of the triceps brachii. Two-thirds of the MVC. Subject Y.

shows the changes of the relative amplitude of each frequency band, which is the per cent ratio of each integrated amplitude to the total activity, in the triceps brachii recorded from one subject. In most cases (49 cases) the component below $60 \mathrm{~Hz}$ increased in the relative amplitude, and the component above 60 $\mathrm{Hz}$ decreased. In six cases the component below $100 \mathrm{~Hz}$ increased and the component above $100 \mathrm{~Hz}$ decreased. In three cases the component below $40 \mathrm{~Hz}$ increased and the component above $40 \mathrm{~Hz}$ decreased. The slow wave ratio was calculated as the proportion(\%) of the integrated amplitude 


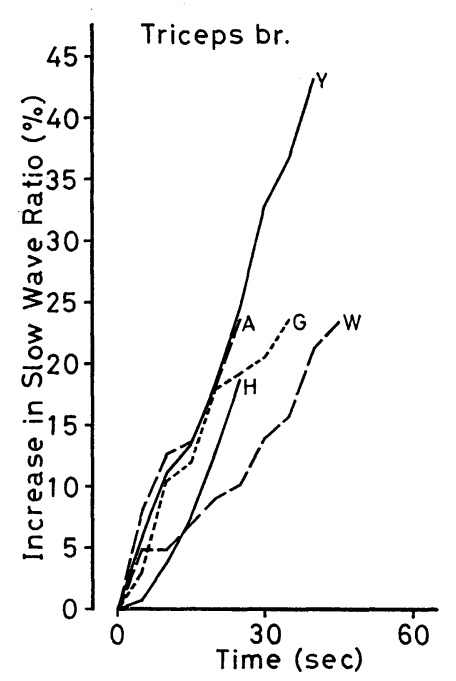

Fig. 2. Changes of slow wave ratio in the EMG of the triceps brachii in five subjects (A, G, H, W and Y). Two-thirds of the MVC. in the frequency component below $60 \mathrm{~Hz}$ to the total activity. The slow wave ratio at the beginning of the contraction varied among muscles in the same subject and among subjects in the same muscle from $21.5-33.5 \%$ in the gastrocnemius to $42.3-$ $54.1 \%$ in the brachioradialis. In order to compare the degree of frequency lowering in the EMG, the increase in slow wave ratio, that is each slow wave ratio minus initial slow wave ratio, was calculated. Since the degree of frequency lowering showed interindividual variations in the same muscle at the same contraction level as shown in Fig. 2, the EMGs of the examined muscles were compared at the same contraction level in the same subject.

As for elbow extensor and flexors, the frequency lowering was more remarkable in the triceps brachii than in the biceps brachii and the brachioradialis, whether subject contracted the muscle against a load or he did using the tension-meter

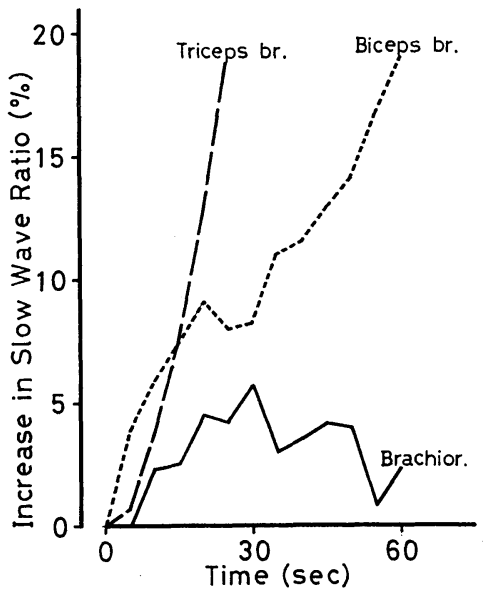

Fig. 3. Changes of slow wave ratio in the EMG of the triceps brachii, biceps brachii and brachioradialis. Two-thirds of the MVC. Subject $H$.

(Fig. 3). No significant difference in the degree of the frequency lowering was observed between the biceps brachii and the brachioradialis in four cases, and the biceps brachii showed greater frequency lowering than the brachioradialis in three cases. The extensor carpi ulnaris showed more marked frequency lowering as compared with the flexor carpi ulnaris

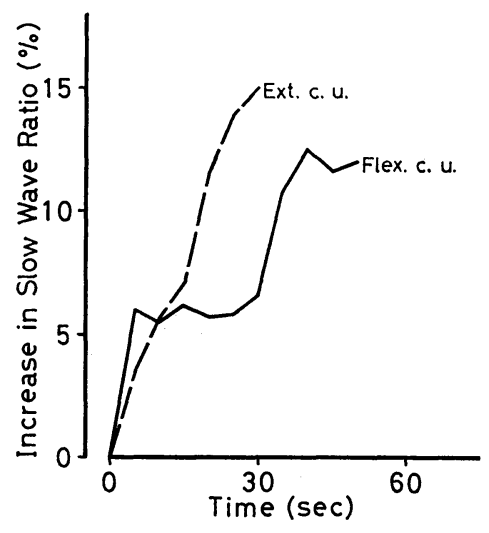

Fig. 4. Changes of slow wave ratio in the EMG of the extensor and flexor carpi ulnaris. Two-thirds of the MVC. Subject Y. 


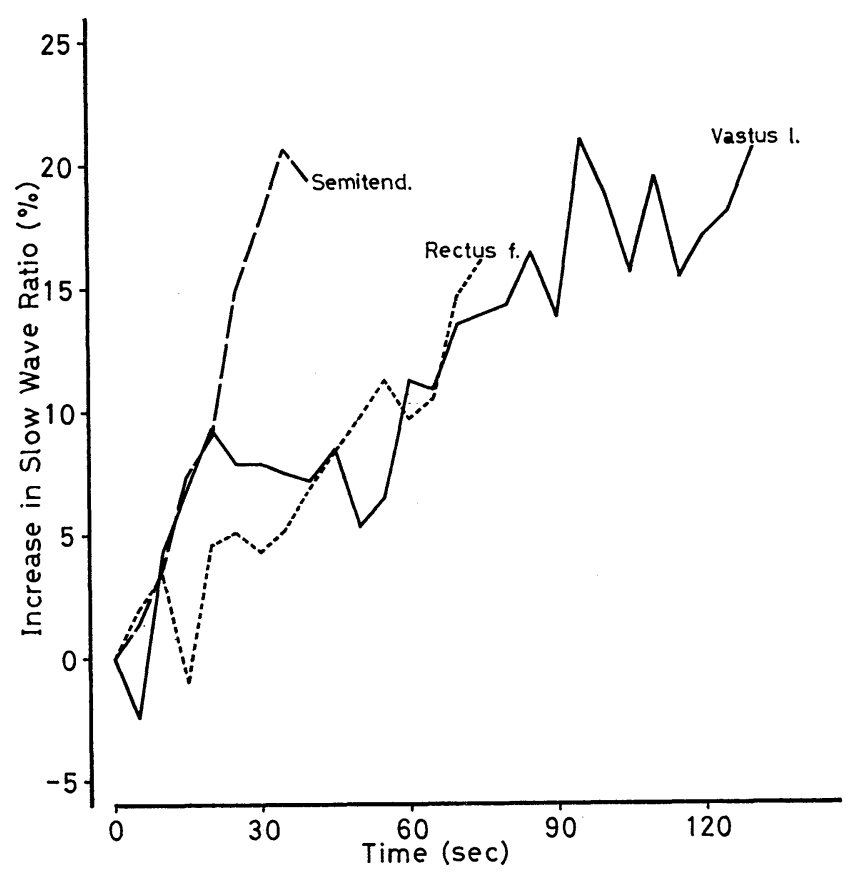

Fig. 5. Changes of slow wave ratio in the EMG of the semitendinosus, rectus femoris and vastus lateralis. Two-thirds of the MVC. Subject W.

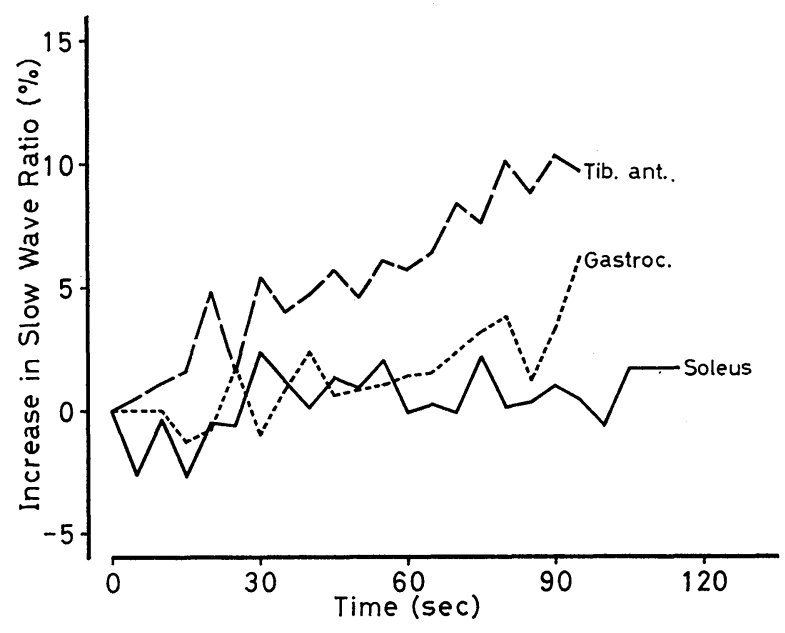

Fig. 6. Changes of slow wave ratio in the EMG of the tibialis anterior, gastrocnemius and soleus. Two-thirds of the MVC. Subject M.

$$
\begin{aligned}
& \text { Triceps br. }>\text { Biceps br. } \geq \text { Brachior. } \\
& \text { Semitend. Ext. c. u.>Flex. c. u. }>\text { Rectus } \mathrm{f} . \fallingdotseq \text { Vastus m. } \cong \text { Vastus } 1 \text {. } \\
& \begin{array}{l}
>\text { Rectus } f .=\text { Vastus m. } \\
\text { Tib. ant. }
\end{array}
\end{aligned}
$$

Fig. 7. Fatiguability for sustained isometric contraction of twelve human limb muscles.
(Fig. 4). As for the thigh muscles, the semitendinosus showed the most remarkable tendency of slow component increase, and this tendency was not so marked in the rectus femoris, vastus medialis and vastus lateralis (Fig. 5). No significant difference was apparent in the degree of frequency lowering among the rectus femoris, vastus medialis and vastus lateralis. The tibialis anterior showed greater frequency lowering than the gastrocnemius and the soleus (Fig. 6). There was no consistent difference in the frequency lowering between the gastrocnemius and the soleus.

The results are summarized in 
Fig. 7. As a whole the muscles of the lower limb, especially the knee extensors and the calf muscles, were less fatiguable than the muscles of the upper limb. In the muscles of the upper limb, the extensors were more fatiguable than the flexors; the triceps brachii was more fatiguable than the biceps brachii and the brachioradialis, and the extensor carpi ulnaris was more fatiguable than the flexor carpi ulnaris. No consistent tendency was observed as to the differences in fatiguability between the two-joint muscles and onejoint muscles; the biceps brachii versus the brachioradialis, the rectus femoris versus the vastus medialis and lateralis, and the gastrocnemius versus the soleus.

\section{DISCUSSION}

It has been shown that human skeletal muscles are made up of at least two main tepys of fibers. Histochemically, slow twitch (ST) and fast twitch (FT) fibers are identified mainly based on the myofibrillar ATPase reaction (other nomenclatures have been proposed; see BROOK \& KAISER, 1974). ST fibers generally have high oxidative potential and FT fibers high glycolytic capacity (EssÉn et al., 1975; GoLLNICK et al., 1974). Two types of fibers have also been differentiated by mechanical and electrical properties (BUCHTHAL \& SCHMALBRUCH, 1970; EBERSTEIN \& GOODGOLD, 1968), and two types of motor units distinguished in human skeletal muscles (Gydikov \& Kosarov, 1974; Tokizane \& SHimazU, 1964).

Most human muscles are mixture of two fiber types distributed in a mosaic pattern throughout the muscle, and the fiber composition varies from muscle to muscle (Buchthal \& Schmalbruch, 1970 ; EDSTRÖM \& NYSTRÖM, 1969; JOHNSON et $a l ., 1973$; Gollnick et al., 1974). Differences in the fiber composition have also been observed within the same muscle comparing different subjects. Recently the interdependence between physical performance and muscle fiber composition has been presented. HULTÉN et al. (1975) demonstrated that isometric endurance time at $50 \%$ MVC was positively correlated to the percentage of ST fibers in the vastus lateralis. THORSTENSSON et al. (1976a) presented that subjects with muscles rich in FT fibers exhibited a higher maximal contraction velocity and also a higher force output during maximal voluntary isokinetic contractions at high speed in the knee extensors. THORSTENSSON \& KARLSSON (1976) showed the positive correlation between fatiguability with rapid maximal voluntary isokinetic contractions and proportion of FT fibers in the quadriceps femoris. The athlete's success in various sport events seems to be related with the percentage distribution of a specific fiber type in skeletal muscles (Costill et al., 1976; Комі et al., 1977a), and the change of fiber composition has never been shown to occur with any form of training (GoLLNICK et al., 1973; THORSTENSSON et al., 1975, 1976b). Recent study on monozygous and dyzygous twins has suggested that the genetic component is of significance for the interindividual variation in fiber composition (KOMI et al., 1977b). 
Fatiguability for sustained isometric contraction of main human limb muscles was investigated in the present study. In order to compare the muscle fatiguability, the contraction level has to be made uniform. However, it is practically impossible to measure the tension of individual muscle. Most of the investigators have demonstrated a linear relationship between the integrated surface EMG and isometric tension in the biceps brachii (KoGI \& HaKamada, 1962b), the deltoid (SAdoyaMA \& KoGI, 1970), the gastrocnemius (LipPOLD, 1952), the soleus (EDwARDS \& LiPPOLD, 1956) and small muscles like the first dorsal interossei (STEPhens \& TAYLOR, 1972), although some investigators reported nonlinear relationship (KURODA et al., 1970; OKADA, 1975). In the present study the contraction level was determined by the linear relation between the integrated EMG and isometric tension.

The endurance time has sometimes been used to evaluate fatiguability (MOLBECH \& Johansen, 1973). Generally speaking a correlation was observed between the degree of frequency lowering of the surface EMG and the endurance time in the present study; the shorter the endurance time, the greater the degree of the EMG frequency lowering. It seemd likely, however, that the endurance times were not determined by the examined muscles in some cases. It has been demonstrated that the amplitude of the surface EMG increases during a sustained contraction (KADEFORS et al., 1968; Kogi \& HAKAMADA, 1962a ; KURODA et al., 1970 ; LiPPold et al., 1960; SADOYAMA \& KogI, 1970;
Sato, 1977). In the present study, however, the total electrical activity did not always increase during contractions. This might suggest the migration of activity from the examined muscle to its synergists (LipPOLD et al., 1960 ; SATO, 1977).

The degree of frequency lowering of the surface EMG was used as an objective index of local muscle fatigue. Some ratios have been proposed to evaluate the EMG frequency lowering; slow wave ratio as the proportion of the integrated amplitude of slower comonent below $40 \mathrm{~Hz}$ to that of faster component above $40 \mathrm{~Hz}$ (KogI \& HaKamada, 1962b; OKada et al., 1970), and as the proportion of the integrated amplitude of slower component below 30 $\mathrm{Hz}$ (Chaf Fin, 1973), or below $40 \mathrm{~Hz}$ (TAniI et al., 1972; YAMASAKI et al., 1977), or below $64 \mathrm{~Hz}$ (SAto \& IsHII, 1977) to the total activity. Differences in indicators of the EMG frequency lowering are in part related to the differences in frequency analysis technique of the EMG data. In the present study the slow wave ratio was calculated as the proportion (\%) of the integrated amplitude in the frequency component below $60 \mathrm{~Hz}$ to the total activity. The differences in initial slow wave ratio observed among muscles would reflect different EMG frequency spectrum patterns of muscles (Kogi \& HAKAMADA, 1962a; SAto, 1976). The increase in slow wave ratio from initial slow wave ratio during a sustained contraction was calculated to evaluate muscle fatigue. If the proportion of the integrated amplitude inthe component below the frequency band, up to which the relative amplitude in- 
creased, to the total activity was used in exceptional cases ( 9 cases), the results were same.

The surface EMG frequency shift may be explained by a increase in the time duration of motor unit action potentials (LIPPOLD et al., 1960), a decrease in discharge frequency of a motor unit (GYDIkov \& Kosarov, 1974 ; Person \& Kudina, 1972) and the grouping of motor unit discharges (KADEFORS et al., 1968; KoGI \& HAKAMADA, 1962a ; LipPold et al., 1960) which might be related to increased polyphasic action potentials (YAMASAKI et al., 1977). Gydikov \& Kosarov (1974) distinguished two types of motor units in the biceps brachii in man and found that reduction of the discharge frequency occurred in the phasic motor unit with relatively high threshold and not in the tonic motor unit with relatively low threshold; in other words the phasic units were more fatiguable than the tonic units. It is conceivable that the muscle with more phasic units may show greater frequency lowering of the surface EMG.

The differences in fatiguability of the examined muscles are presented in Fig. 7. This findings are in general agreement with other reports. KADEFORS et al. (1968) demonstrated that the vastus medialis and lateralis were less affected by a maximum contraction than were the biceps brachii and the brachioradialis with respect to spectral modifications of the EMG. MoLBECH \& JoHANSEN(1973) demonstrated that isometric endurance time at $50 \% \mathrm{MVC}$ was longer in the soleus than the tibialis anterior. No remarkable difference in the fatiguability between the one-joint muscles and two-joint muscles confirmed the work of SATo et al. (1965). Although Sato et al. (1965) stated that the gastrocnemius was more fatiguable than the soleus, they did not make the contraction strength uniform between muscles in their experiments.

Different fatiguability could be explained by differences in the fiber composition. Buchthal \& Schmalbruch(1970) measured the contraction time of twitches of small bundles of fibers. They showed that long contraction times (longer than $60 \mathrm{msec}$ ) predominated in the soleus and the gastrocnemius, comprised half the times in the tibialis anterior, a third in the biceps brachii and a few per cent in the triceps brachii, and that the histograms of contraction times agreed with histochemical findings; long contraction times corresponded to fibers rich in mitochondria (ST fibers). JoHnson et al. (1973) studied the distribution of fiber types in thirty-six muscles and showed particularly high proportions of Type I fibers(ST fibers) in the soleus(87\%), the adductor pollicis (80\%) and the tibialis anterior(73\%), and high proportion of Type II fibers (FT fibers) in the orbicularis oculi (84.6\%), the triceps brachii(67.5\%) and the sternomastoid(64.8\%). The vast majority of the muscles, including the biceps brachii, brachioradialis, gastrocnemius, vastus medialis and vastus laterals, had between $40 \%$ and $70 \%$ of Type I fibers. EDSTRöM \& Nyström(1969) found that the soleus was made up of about $70 \%$ red fibers (ST fibers), the tibialis anterior and the 
gastrocnemius about 60\%, the vastus lateralis $50-70 \%$ and the biceps brachii 40-50\%. GollniCK et al. (1974) demonstrated that the soleus possessed a higher percentage of ST fibers(80\%) than the gastrocnemius and the vastus lateralis (57\%). The discrepancy has been found in the difference of fiber composition between the gastrocnemius and the soleus as mentioned above. In the present study no consistent difference in the fatiguability was observed between the gastrocnemius and the soleus.

The differences in fatiguability for sustained isometric contraction observed in human limb muscles could be attributed to differing functional demands on individual muscles, that would reflect physical characteristics of man.

\section{ACKNOWLEDGMENT}

We wish to thank professor Masahiko SAto, Department of Ergonomics, Kyushu Institute for Design Research, for his guidance and encouragement.

\section{REFERENCES}

BRooK, M.H. \& K.K. KAISER, 1974: The use and abuse of muscle histochemistry. Ann. N. Y. Acad.Sci., 228: 121-144.

Buchthal, F. \& H. SchmalbRuch, 1970 : Contraction times and fibre types in intact human muscle. Acta physiol.scand., 79: 435452.

CHAFFIN, D. B., 1973: Localized muscle fatigue -definition and measurement. J. Occup. Med., 15: 346-354.

Costill, D. L., J. Daniels, W. Evans, W. Fink, G. KRAHENBuhl \& B. Saltin, 1976: Skeletal muscle enzymes and fiber composition in male and female track athletes. J. Appl.Physiol., 40: 149-154.
Eberstein, A. \& J. Goodgold, 1968: Slow and fast twitch fibers in human skeletal muscle. Am. J. Physiol., 215 : 535-541.

EDSTRÖM,L. \& B. NYSTRÖM, 1969: Histochemical types and sizes of fibres in normal human muscles. Acta Neurol.Scand., 45: 257-269.

EDwARDS, R.G. \& O.C. J. LiPpold, 1956: The relation between force and integrated electrical activity in fatigued muscle. J. Physiol., 132: 677-681.

Essén, B., E. Jansson, J. Henriksson, A. W. TAYLOR \& B.SALTIN, 1975: Metabolic characteristics of fibre types in human skeletal muscle. Acta physiol.scand., 95: 153-165.

Gollnick, P.D., R.B.ARMSTRONG, B.SAltin, C. W. Saubert IV, W. L. Sembrowich \& R.E. SHEPHERD, 1973: Effect of training on enzyme activity and fiber composition of human skeletal muscle. J.Appl.Physiol., 34 : 107-111.

Gollnick, P.D., B. SJödin, J. KaRlsson, E. JANSSON \& B. SALTIN, 1974: Human soleus muscle, a comparison of fiber composition and enzyme activities with other leg muscles Pflügers Arch.ges. Physiol., 348: 247-255.

Gydikov, A. \& D. KosARov, 1974: Some features of different motor units in human biceps brachii. Pflügers Arch.ges. Physiol., 347 : 75-88.

Hultén, B., A. Thorstensson, B. SJödin \& J.KARLSSON, 1975: Relationship between isometric endurance and fibre types in human leg muscles. Acta physiol.scand., 93: 135-138. Johnson, M.A., J. Polgar, D. Weightman \& D. Appleton, 1973: Data on the distribution of fibre types in thirty-six human muscles, an autopsy study. J. Neurol. Sci., 18: 111-129.

KADEFORS, R., E. KAISER \& I. PETERSÉN, 1968: Dynamic spectrum analysis of myo-poten. tials and with special reference to muscle fatigue. Electromyography, 8: 39-74.

KADEFors, R., I. Petersén \& P. Herberts, 1976: Muscular reaction to welding work, an electromyographic investigation. Ergonomics, 19: 543-558. 
KoGI, K. \& T. HAKAMADA, 1962a: Erequency analysis of the surface electromyogram in muscle fatigue. J. Sci. Labour, 38: 519-528 (In Japanese with English abstract).

KOGI, K. \& T. HAKAMADA, 1962b: Slowing of surface electromyogram and muscle strength in muscle fatigue. Rep. Inst. Sci. Labour, $60: 27-41$.

Kомi, P. V., H. Rusko, J. Vos \& V. Viнко, 1977a: Anaerobic performance capacity in athletes. Acta physiol. scand., 100: 107-114.

Komi, P. V., J. H. T. Virtasalo, M. HavU, A. ThorstensSON, B. SJÖDIN \& J.KARLSSON, 1977b: Skeletal muscle fibres and muscle enzyme activities in monozygous and dizygous twins of both sexes. Acta physiol.scand., $100: 385-392$.

Kuroda, E., V. Klissouras \& J. H. Milsum, 1970: Electrical and metabolic activities and fatigue in human isometric contraction. J. Appl. Physiol., 29 : 358-367.

LiPPolD, O. C. J., 1952: The relation between integrated action potentials in a human muscle and its isometric tension. J. Physiol., 117 : 492-499.

Lippold, O. C. J., J. W. T. REDFEARN \& J. Vučo, 1960: The electromyography of fatigue. Ergonomics, 3: 121-131.

Molbech, S. \& S. H. Johansen, 1973: Endurance time in slow and fast contracting muscle groups. Work environm. Health, 10 : 62-64.

NAPIER, J., 1962: The evolution of the hand. Sci. Am., 207(6): 56-62.

NAPIER, J., 1967: The antiquity of human walking. Sci. Am., 216(4): 56-66.

OKADA, M., 1975: Quantitative studies on the bearing of the anti-gravity muscles in human postures with special references to electromyographic estimation of the postural muscle load. J. Fac. Sci. Univ. Tokyo, V-4: 471-530.

OKADA, M., K. Kogi \& M. IshiI, 1970: Enduring capacity of the erectores spinae muscles in static work. J. Anthrop. Soc. Nippon, 78: 99-110.

Person, R. S. \& L.P. Kudina, 1972: Discharge frequency and discharge pattern of human motor units during voluntary contraction of muscle. Electroenceph. clin. Neurophysiol., 32 : 471-483.

SADOYAMA, T. \& K. KogI, 1970: On aboveshoulder work area for manual operation. Japanese J.Ergonomics, 6: 45-50 (In Japanese with English abstract).

SATO, H., 1976: Power spectral analysis of surface electromyograms during isometric contractions. J. Anthrop. Soc. Nippon, 84: $1-14$.

SAтo, H., 1977: Electromyographic study of muscle fatigue in sustained isometric contractions. J. Anthrop. Soc. Nippon, 85: 83-94. SATO, H. \& M. Ishil, 1977: Evaluation of local muscle fatigue in dynamic muscular work. Japanese J. Ergonomics, 13: 255-260 (In Japanese with English abstract).

Sato, M., 1964: Frequency components of the electromyogram led with the bipolar surface electrodes. J. Anthrop. Soc. Nippon, 72 : 92-106 (In Japanese with English abstract).

Sato, M., 1966: Muscle fatigue in the half rising posture. J. Anthrop. Soc. Nippon, 74 : 195-201.

Sato, M., A. Hayami \& H. Sato, 1965: Differential fatiguability between the one- and two-joint muscles. J. Anthrop. Soc. Nippon, 73: 82-90.

SATO, M. \& Y. SAKAI, 1968: Isometric and eccentric strength of elbow flexors and extensors. J. Anthrop. Soc. Nippon, 76: 183-190.

Stephens, J. A. \& A. TAylor, 1972: Fatigue of maintained voluntary muscle contraction in man. J. Physiol., 220: 1-18.

TANiI, K., K. Kogi \& T. SAdoyama, 1972 : Spontaneous alternation of the working arm in static overhead work. J. Human Ergol., 1: 143-155.

Thorstensson, A., G. Grimby \& J. KarlsSON, 1976a : Force-velocity relations and fiber composition in human knee extensor muscles. J. Appl. Physiol., 40: 12-16.

Thorstensson,A.,B. Hultén, W. von DöBeln \& J. KARLSSON, 1976b: Effect of strength 
training on enzyme activities and fibre characteristics in human skeletal muscle. Acta physiol. scand., 96 : 392-398.

Thorstensson, A. \& J. KARLSSON, 1976: Fatiguability and fibre composition of human skeletal muscle. Acta physiol. scand., 98: 318-322.

Thorstensson, A., B. SJÖDIN \& J. KARLSSON, 1975: Enzyme activities and muscle strength after "sprint training" in man. Acta physiol. scand., $94: 313-318$.

Tokizane, T. \& H. ShimazU, 1964: Functional differentiation of human skeletal muscle. Univ. of Tokyo Press, Tokyo.

YAMASAKI, M., K. YAMASAKI \& H. HisANAGA, 1977: Changes of the motor unit activities in muscle fatigue. J. Anthrop. Soc. Nippon, 85: 229-236 (In Japanese with English abstract).

(Received November 29, 1977)

ヒトの骨格筋における疲労性の相違

\section{佐藤 陽彦1)・早弓惇2 \\ 1) 九州芸術工科大学 人間工学教室 \\ 2) 日本女子体育大学 人類学運動力学研究室}

局所筋疲労に伴って生じる表面筋電図周波数スペクトルの徐波化の程度を示標にして，等尺性収縮に対する 四肢骨格筋の疲労性の相違について研究した。

収縮の強さは最大収縮の 3 分の 2 或は 2 分の 1 とし, 等尺性収縮を疲僙に至るまで続けた時の双極表面筋電 図を，7つの帯域フィルターをむった自動周波数分析装置によって 5 秒間毎に周波数分析した。筋電図の徐波 化の程度を比較するために, $60 \mathrm{~Hz}$ 以下の周波数成分の全周波数成分に対する百分率を徐波比とし, 収縮開始 時の徐波比加らの徐波比の増加量を求めた。

上腕三頭筋は上腕二頭筋及び腕橈骨筋より疲労しやすく, 上腕二頭筋が腕橈骨筋より疲労しやすい場合もあ った。尺側手根伸筋は尺側手根屈筋よりも疲労しやすい。下肢では，半腱様筋が大腿直筋や内側広筋や外側広 筋より疲労しやすいが, 後三者の間には疲労性の相違は認められなかった。前脛骨筋は下腿三頭筋より疲労し やすく，腓腹笳とヒラメ筋の間には一定した疲労性の相違は見出せなかった。一般に，下肢の筋，特に大腿四 頭筋と下腿三頭筋は上肢の筋より疲労しにくい。上肢においては，伸筋の方が屈筋より疲労しやすい。一関節 性筋と二関節性筋との間には疲労性の相違は観察されなかった。ヒトの骨格筋にみられる疲労性の相違は, 速 筋瀻維と遅筋䋐維の分布の差異によってもたらされ，ヒトの身体的特性を反映しているものと考えられる。 